UDC 004.942:625.7/8

DOI: $10.15587 / 2706-5448.2021 .237949$

Article type «Reports on Research Projects»

\title{
Nikolay Dmytrychenko, DEVELOPMENT OF METHOD FOR ROAD NETWORK MANAGEMENT PROGRAM OPTIMIZATION
}

The object of research is the processes of road network management. The main hypothesis of the study is the application of optimization methods to the road asset management program, which allows to implement a road maintenance strategy, which includes a set of measures involved in ensuring and maintaining roads at the appropriate operational level. In general, the sequence of asset management begins with the definition of objectives, policy of road administrations and the available budget. According to this starting point, data collection, performance monitoring, analysis of options and optimization programs, selection and implementation of a set of projects are performed. The goals and objectives of road project management depending on the category are considered. The model of strategic planning of the program on management of a network of highways is offered and the modern architecture of model is constructed. The main approaches to the optimization of the road asset management program are identified. The target function for the optimization model is proposed, which is to minimize the cost of maintenance of the road network and defines the goals to be achieved in the optimization process. The optimization model is a mathematical description designed to compare alternative strategies and identify the relative benefits of each strategy according to the assigned decision criteria, such as safety, cost, environment and others. The main idea and goal of road network management projects is to improve maintenance practices and policies and thus improve the condition of the network, or maintain it at the current level, taking into account resource constraints. The results of program optimization have practical value and can be used to manage road repair and operation projects depending on:

- defined project goals and plans, including scheduling, budgeting, planning, established efficiency requirements and selection of project participants;

- maximizing the efficient use of resources;

- implementation of functions of coordination and control, planning, design, evaluation, conclusion of contracts and implementation of projects under contracts.

Keywords: optimization method, control program, road project, road network.

\section{How to cite}

Dmytrychenko, N., Kharchenko, A. (2021). Development of method for road network management program optimization. Technology Audit and Production Reserves, 4 (2 (60)), 56-60. doi: http://doi.org/10.15587/2706-5448.2021.237949

\section{Introduction}

Decreasing funds for transport infrastructure projects prompts the development and implementation of costeffective procedures for the preservation and restoration of road assets. The basic philosophy of conservation provides for a long-term and cost-effective program, applied at the project level with strategic programming, which covers the entire road network.

Management of road repair and maintenance projects requires knowledge of modern management, as well as an understanding of the processes occurring at different stages of the road life cycle. Construction projects have a certain set of goals and restrictions, time, material, technical and technological parameters. Although the respective technologies, institutional arrangements or processes will differ, the management of such projects has much in common with the management of similar types of projects in other industries such as aerospace, environmental, energy, etc.

According to the Institute for Project Management, the term «project management» can be defined as follows [1]. It is the art of managing and coordinating human and material resources throughout the life of a project, using modern management techniques to achieve predetermined goals in terms of volume, cost, time, quality and enjoyment of participation.

Thus, the management of road repair and maintenance projects encompasses a set of goals that can be achieved through a number of operations falling under resource constraints and further form the road network management program. A road asset management program is a description of specific activities or a set of projects required to achieve the objectives of a road agency, including detailed annual work programs [2].

However, there are potential conflicts between the stated objectives in terms of volume, cost, time, quality and 
the constraints imposed on human material and financial resources. These conflicts should be resolved early in the project by making the necessary compromises or creating new alternatives, achieved by optimizing the road asset management program.

The object of research is the processes of road network management. The aim of research is to develop a method for optimizing the program for managing the road network.

\section{Methods of research}

The objectives of the asset management system are related to the performance of the road network and reflect the vision of what the network management system should achieve in the future. Understanding of different kinds of goals is crucial for determining a set of performance indicators for highways that should be included in the management process (Table 1) [3].

Cost-effective methods and procedures for maintaining and restoring road assets are critical to increasing their longevity and extending their useful life.

A successful program for the conservation and restoration of road assets lies in the application of correct data processing and timely planning of activities (Fig. 1).

In 1997, a study has been conducted that provides examples of decision trees and matrix-based methods to select suitable alternatives to strategies [2] for managing the road network. However, at the initial stage, external influences and additional restrictions, such as, for example, road safety measures, environmental factors, and the like, were not taken into account.

Thus, it became necessary to develop a tool that would include in the decision-making system for road network management a set of measures and restrictions that would allow determining the optimal program (Fig. 2).

The block of control models includes - a model for managing the state of an asset, a model for assessing the effectiveness of a project for a consumer, a model for managing transport and operating costs, a model for managing safety, energy conservation, environmental impact, a model for determining the effect of repair and restoration measures, a model for project costing.

The programming of projects is shaped by the strategic goals of the road agency, which are influenced by external factors and resource constraints. The programming process associated with planning and feasibility studies sets the priorities and timing for initiating various projects to achieve the overall goals of the road agency for the management of the road network [4].

The repair and maintenance project management system is a set of tools for finding optimal strategies for keeping road assets in good working order. At the road network level, programs are designed in such a way that the overall cost-effectiveness and other effects are maximized over a period of analysis. At the project level, detailed consideration is usually given to alternative projects within an overall program that will provide the desired benefits or network service level at the lowest total cost over the analysis period.

The project manager has the greatest influence on costs in the construction phase of the project, since any decision made at the initial stage of the project life cycle has a much greater impact than decisions made at later stages (Fig. 3) [4, 5].
Table 1

Examples of goals and objectives of road project management by category

\begin{tabular}{|c|c|c|}
\hline Category & Goals & Objectives \\
\hline $\begin{array}{l}\text { Preserva- } \\
\text { tion of the } \\
\text { network }\end{array}$ & $\begin{array}{l}\text { Preserve road infrastructure, } \\
\text { taking into account the level of } \\
\text { government funding and other } \\
\text { restrictions }\end{array}$ & $\begin{array}{l}\text { Use innovative technology and } \\
\text { materials to minimize work } \\
\text { delays and improve the life } \\
\text { of road assets }\end{array}$ \\
\hline $\begin{array}{l}\text { Operational } \\
\text { efficiency }\end{array}$ & $\begin{array}{l}\text { Develop strategies that improve } \\
\text { human and freight transport by } \\
\text { reducing delays and minimizing } \\
\text { discomfort }\end{array}$ & $\begin{array}{l}\text { Use economies of scale by } \\
\text { enabling intermodal sharing }\end{array}$ \\
\hline Availability & Provide reasonable availability & $\begin{array}{l}\text { Provide access to the popula- } \\
\text { tion who can receive appro- } \\
\text { priate services }\end{array}$ \\
\hline Mobility & $\begin{array}{l}\text { Provide basic mobility for all } \\
\text { communities by providing safe, } \\
\text { efficient and cost-effective ac- } \\
\text { cess to work, educational oppor- } \\
\text { tunities and essential services }\end{array}$ & $\begin{array}{l}\text { Provide travel times with pub- } \\
\text { lic transport competitive for } \\
\text { passenger cars }\end{array}$ \\
\hline $\begin{array}{l}\text { Economic } \\
\text { develop- } \\
\text { ment }\end{array}$ & $\begin{array}{l}\text { Pay attention to expected de- } \\
\text { mand from increased trade }\end{array}$ & $\begin{array}{l}\text { Improve access to passenger } \\
\text { and freight traffic for service } \\
\text { commerce }\end{array}$ \\
\hline $\begin{array}{l}\text { Quality of } \\
\text { life }\end{array}$ & $\begin{array}{l}\text { Ensure that highway invest- } \\
\text { ments are cost-effective, protect } \\
\text { the environment, and promote } \\
\text { energy efficiency }\end{array}$ & $\begin{array}{l}\text { Introduce measures for safe, } \\
\text { comfortable traffic, minimizing } \\
\text { environmental impact }\end{array}$ \\
\hline Safety & $\begin{array}{l}\text { Ensure high safety standards } \\
\text { in the transport system }\end{array}$ & $\begin{array}{l}\text { Reduce vehicle-related deaths, } \\
\text { injuries and property losses }\end{array}$ \\
\hline $\begin{array}{l}\text { Resources } \\
\text { and envi- } \\
\text { ronment }\end{array}$ & $\begin{array}{l}\text { Develop environmentally friend- } \\
\text { ly projects }\end{array}$ & $\begin{array}{l}\text { Improve the quality of the } \\
\text { environment through appro- } \\
\text { priate measures }\end{array}$ \\
\hline
\end{tabular}

Construction project decisions affect fixed operating costs and, in many cases, benefits over the life of the road asset $[6,7]$. The target function of maximizing the efficiency of the project is:

$$
\max \sum_{i}^{n}\left(100-x_{i}\right) \omega_{i}
$$

which can be represented as follows:

$$
\max \sum_{i=1}^{n} \Delta x_{i} \omega_{i}
$$

where $\omega_{i}$ - weight of the target level for each component and goal in the program; $n$ - the total number of goals in the program. 


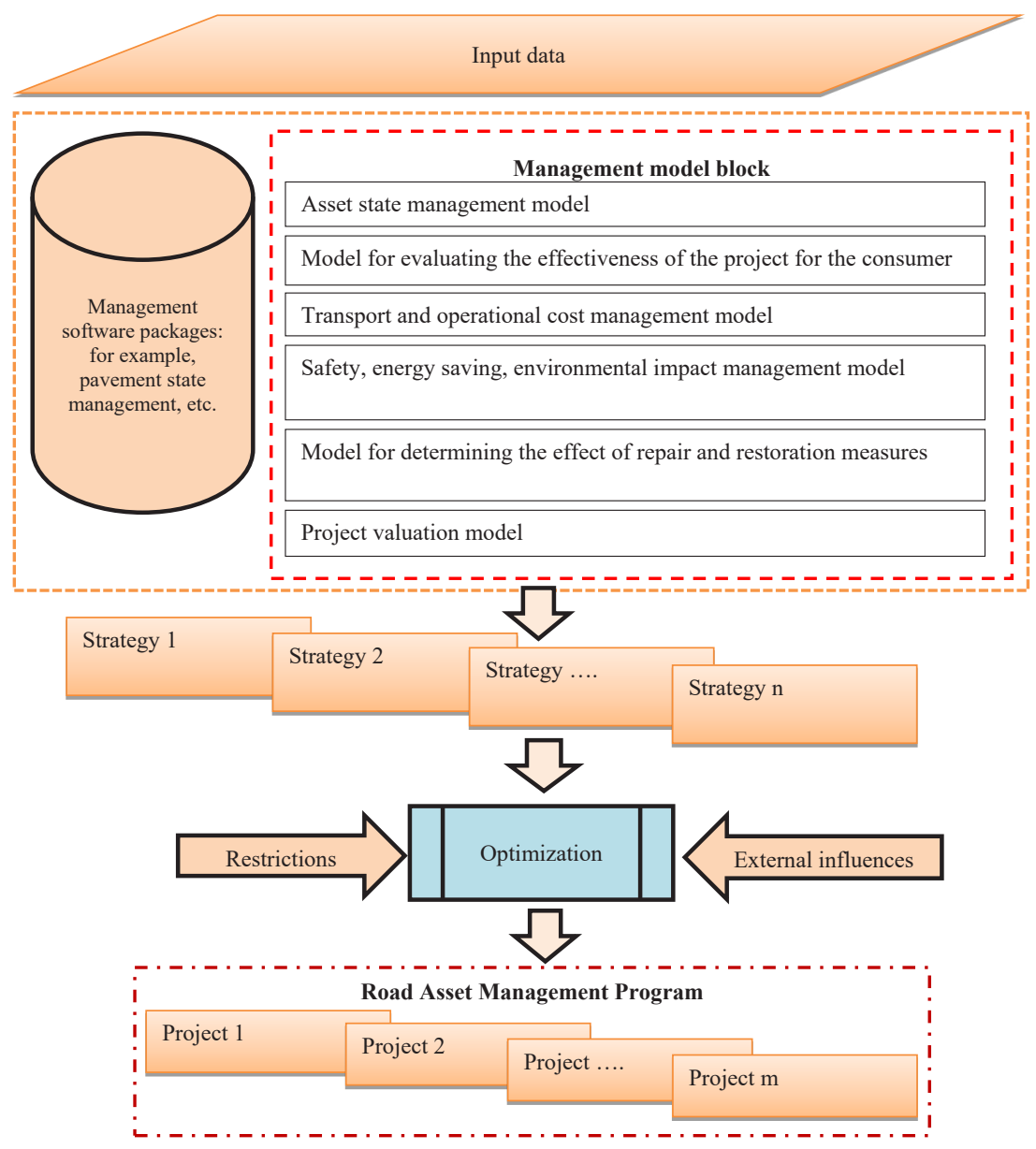

Fig. 2. Architecture of the management model for road projects

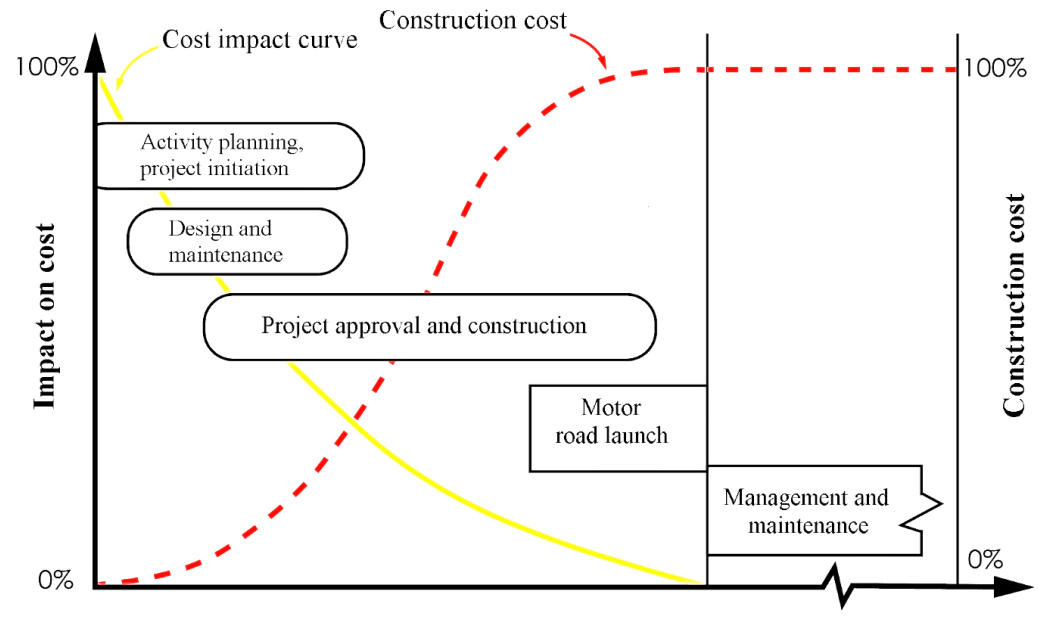

Fig. 3. The ability to influence the cost of activities over time
There is also a limitation on negativity at the function level:

$$
\left(\frac{100}{t_{i}}+\Delta x_{i}\right) c_{i} \geq 0
$$

The target deficit level $x_{i}$ is related to the current deficit level $x_{i}^{\prime}$ and the decrease in speed:

$$
x_{i}=x_{i}^{\prime}-\Delta x_{i} .
$$

The constraints on changing the deficit are:

$$
\begin{aligned}
& \Delta x_{i} \leq x_{i}^{\prime}, \\
& x_{i} \leq \max \left(x_{i}\right) .
\end{aligned}
$$

The limitation $\Delta x_{i} \leq x_{i}^{\prime}$ means that the deficit can't be reduced by more than its current value.

The limitation $x_{i} \leq \max \left(x_{i}\right)$ requires that the objective function does not exceed the maximum acceptable norm.

The objective function of the optimization model determines the goals to be achieved in the optimization process [8,9]. An objective function can be defined to minimize the overall maintenance costs of the road network and maximize pavement/efficiency in terms of improving the pavement condition index or reducing the number of defects. The proposed objective function for the optimi- 
zation model is to minimize the cost of maintaining the road network:

$$
\sum_{m=1}^{M} \sum_{s=1}^{S} \sum_{t=1}^{T} X_{m s t} \cdot L_{S} \cdot C_{s m t} \cdot(1+R)^{t}, \forall s, m, t
$$

where $X_{m s t}$ - measure (repair, maintenance) $m$ applied on the road section $s$ during the time $t(\mathrm{~m}) ; C_{s m t}-$ cost of the measure $m$ applied on the road section $s$ at time $t$ (monetary units $/ \mathrm{km}) ; L_{S}$ - section length $s(\mathrm{~km}) ; R$ - discount rate for calculating the present value of future expenses (\%).

Constraints for the optimization process may include budget, minimum performance indicators, effects from repairs, limiting the number of activities in one year [10]:

$$
\begin{aligned}
& \sum_{m=1}^{M} X_{m s t}=1, \forall m, s, t \\
& X_{m s t}=\left\{\begin{array}{l}
1 \\
\text { if activity } m \text { is selected for section } s \text { at time } t \\
0 \text { otherwise, }
\end{array}\right. \\
& \sum_{s=1}^{S} \sum_{m=1}^{M} X_{m s t} \cdot L_{s} \cdot C_{s t m} \cdot(1+R)^{t} \leq B, \text { for } t=1,2,3, \ldots T
\end{aligned}
$$

where $B$ - annual budget in the program, years.

$$
P C I s_{(t)}=F\left(A G E_{s t}\right), \forall s, z, t
$$

where $P C I s_{(t)}$ - predicted pavement condition index for the section $s$ at time $t$, which is a function of the age of the pavement sections in terms of the number of years:

$$
\sum \operatorname{PCIs}_{(t+1)}=\left|\begin{array}{l}
P C I C s_{t}-\left(\text { PCIs }_{t+1}\right)+ \\
+\left(X_{m s t} \cdot \Delta P C I m\right)
\end{array}\right|, \forall s, t, m,
$$

where $\sum$ PCIs $s_{(t+1)}$ - cumulative index of the condition of the road surface for sections for $t+11$ year and the improvement in the condition associated with the implementation of the measure $m$, subject to the restrictions:

$$
\begin{aligned}
& \sum P C I s_{(t+1)} \geq P C I_{\min }, \forall s, t, \\
& \sum P C I s_{(t+1)} \leq P C I_{\max }, \quad \forall s, t,
\end{aligned}
$$

where $P C I_{\min }, P C I_{\max }-$ minimum and maximum indicator of the condition of the road surface, corresponds to the goals set by the road agency (while $P C I_{\min }$ is assigned not lower than the normative one) $P C I \in[0 ; 100],\{P C I \in N\}, P C I_{\max } \leq 100$.

Thus, the project defined according to the proposed method is included in the road asset management program. The task of the developed method is to maximize the effectiveness of the control program. The efficiency equation forms the basis for applying linear programming with different parameters depending on whether the goal is desired or the level of program execution.

\section{Research results and discussion}

Graphical illustrations of the results obtained from the optimization model are presented in Fig. 4-7.

Fig. 5 shows the distribution of costs for the maintenance of projects that fell into the network management program, assuming that the optimal plan consists of the choice of T3, T2, T2, T2 and T2 for 1, 2, 4, 6 and 8 years, respectively.

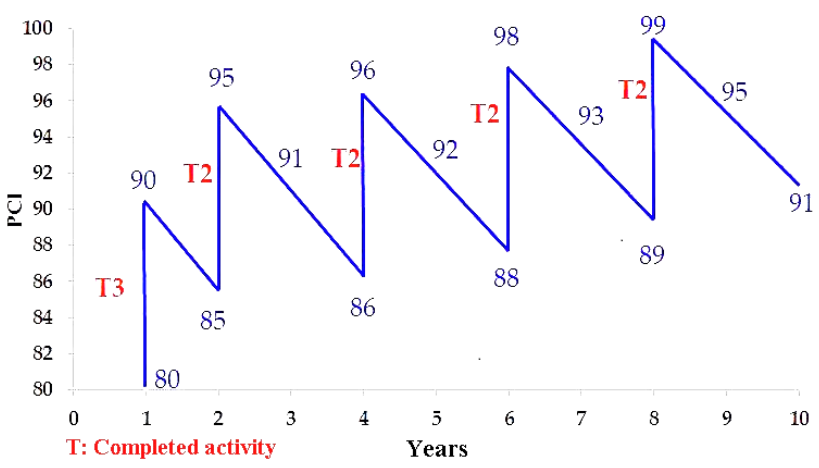

Fig. 4. Pavement Condition Index (PCI) for a section of pavement

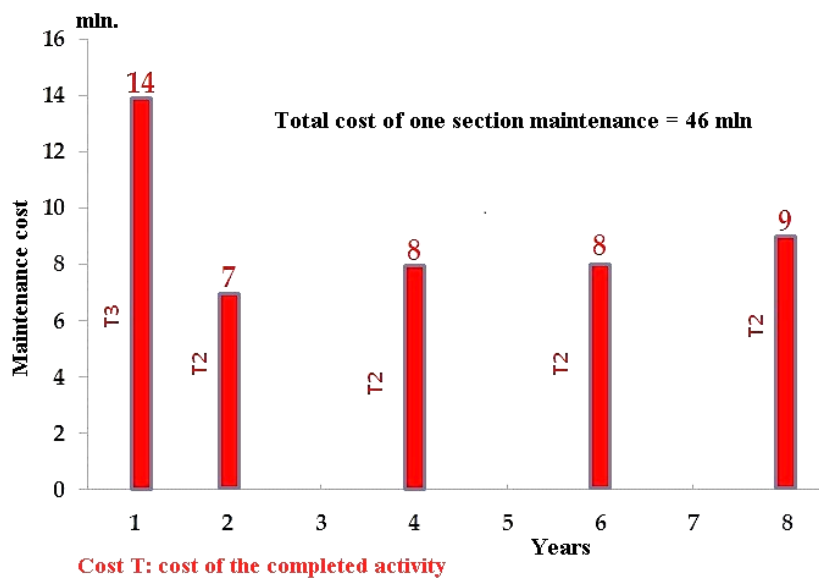

Fig. 5. Estimated costs for the repair of the road section

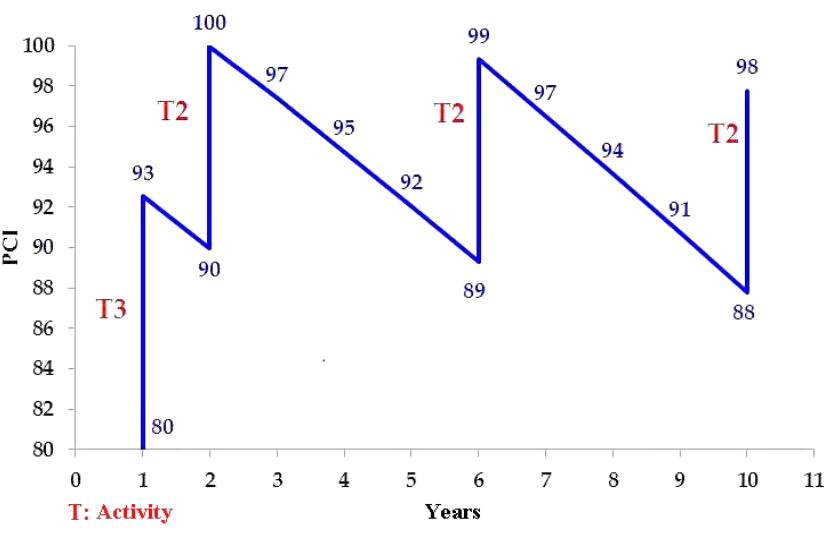

Fig. 6. Pavement Condition Index (PCI) for a road section

Fig. 7 shows the total cost of maintaining the site in the optimization model.

The results of the optimization model indicate the need to implement actions on all road sections in the first year of the program, as the condition index in the first year is below the target of 90 . However, the repair measures were carried out over different years depending on the projected cumulative road condition index. The aggregate index of the state of the road surface in the proposed optimization model makes it possible to take into account not only the current state of the roads, but also the measures that were carried out during the life cycle of the functioning of the network selected for analysis. 


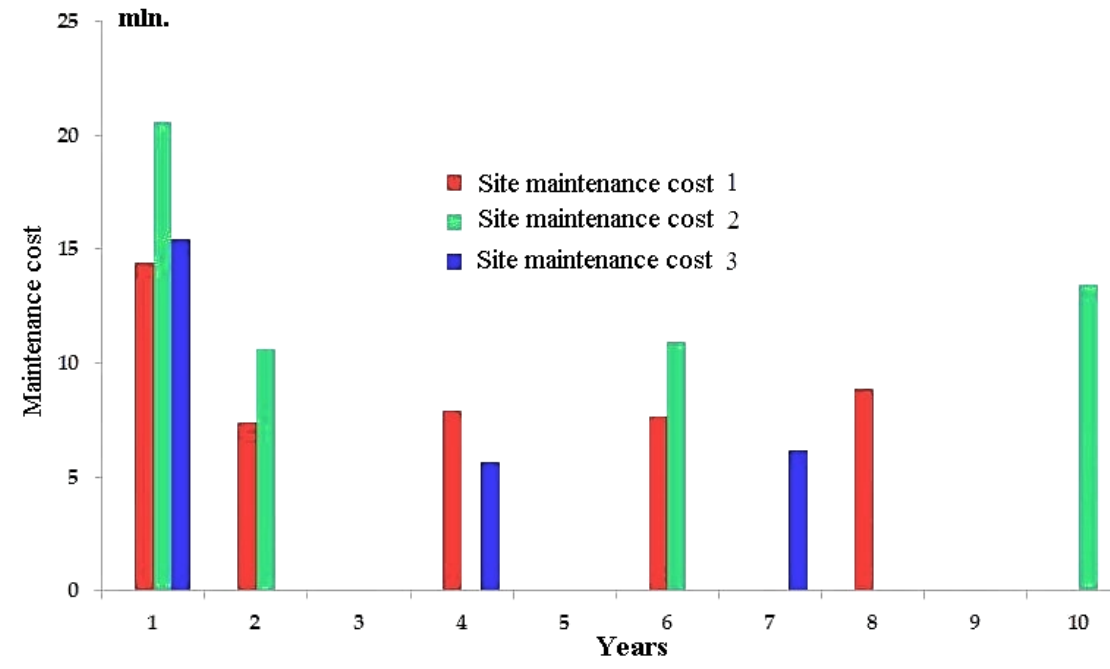

Fig. 7. The total estimated cost of maintaining sites

As a result of this research, a method for optimizing the program for managing the network of highways was proposed, which makes it possible to substantiate the effectiveness of the decisions made to accomplish tasks in the following areas:

1. Management of project integration to ensure effective coordination of the various elements of the project.

2. Project scope management to ensure that all required work (and only work required) is included.

3. Management of the project implementation time to ensure an efficient project implementation schedule.

4. Manage project costs to identify the required resources and maintain budgetary control.

5. Quality management of the project to ensure functional requirements.

6. Human resource management for the development and effective involvement of project personnel.

7. Communications management to ensure effective internal and external communications.

8. Project risk management to analyze and mitigate potential risks.

9. Project procurement management to obtain the necessary resources from external sources.

In further research, this method will be developed taking into account the multi-criteria optimization of the road asset management program.

\section{Conclusions}

In the study, based on the analysis of goals and objectives for the management of road projects, a model of strategic planning of the program for the management of the road network is proposed, a modern architecture of the model is built, and the main fundamental approaches to model optimization are determined.

The target function of the optimization model is determined, which is to minimize the costs of the maintenance of the road network, depending on the pre-design goals. The prioritization of alternative strategies is carried out in accordance with the intended decision criteria, including road safety, the degree of road destruction, cost, ecology, and others.

The optimization of the program for the management of the road network on a conditional example showed that

\section{References} UZBEKISTAN 10986/11777 0003-4223-1838 the condition index in the first year is lower than the target of 90 , therefore, it is necessary to carry out activities on all the road sections under consideration in the first year of the program.

The impact of repair and restoration measures on the operational state in the future was also assessed, which made it possible to increase the total index of the network state.

The results of the optimization of the program are of practical value and can be implemented in management models for projects of the maintenance of the road network in conditions of financial and resource constraints.

1. Norris, J. (2013). Pavement Management Study. Transportation, Land Development, Environmental Services. North Castle, 40.

2. Sodikov, J. (2015). Road asset management systems in developing countries: case study Uzbekistan. Science Journal of Transportation, 6, 48-58. Available at: https://www.researchgate. net/publication/272415247_ROAD_ASSET_MANAGEMENT SYSTEMS_IN_DEVELOPING_COUNTRIES_CASE_STUDY

3. Zhou, Q., Okte, E., Sen, S., Ozer, H., Al-Qadi, I. L., Roesler, J. R., Chatti, K. (2019). Development of a life-cycle assessment tool for pavement preservation and maintenance on flexible and rigid pavement. Final project report Vol. I. Available at: https:// apps.ict.illinois.edu/projects/getfile.asp?id=8865

4. Road Asset Management (2005). Transit New Zealand. Available at: http://www.nzta.govt.nz/resources/chipsealing-new-zealandmanual/docs/05-road-asset-management.pdf

5. Lapidus, A., Makarov, A. (2016). Fuzzy sets on step of planning of experiment for organization and management of construction processes. MATEC Web of Conferences, 86. doi: http://doi.org/ $10.1051 / \mathrm{matecconf} / 20168605003$

6. Dojutrek, M. S., Makwana, P. A., Labi, S. (2012). A Methodology for Highway Asset Valuation in Indiana. Publication FHWA IN/JTRP-2012/31. Joint Transportation Research Program, Indiana Department of Transportation and Purdue University. West Lafayette. doi: http://doi.org/10.5703/1288284315035

7. McNeil, S. (2000). Asset Management and Asset Valuation: The Implication of the Government Accounting Standards Bureau (GASB) Standards for Reporting Capital Assets. Midcontinent Transportation Symposium. Minnesota, 34-37.

8. Switzer, A., McNeil, S. (2004). Developing a Road Map for Transportation Asset Management Research. Public Works Management \& Policy, 8 (3), 162-175. doi: http://doi.org/10.1177/ 1087724x03259475

9. McPherson, K., Bennett, C. R. (2006). Success Factors for Road Management Systems. Transport Notes Series; No. TRN 29. The World Bank. Washington. Available at: http://hdl.handle.net/

10. Robinson, R., Danielson, U., Snaith, M. (1998). Road Maintenance Management. Concepts and Systems. London: Macmillan press Ltd, 312. doi: http://doi.org/10.1007/978-1-349-14676-5

Nikolay Dmytrychenko, Doctor of Technical Science, Professor Department of Production, Repair and Material Sciences, National Transport University, Kyiv, Ukraine, ORCID: https://orcid.org/0000-

$\triangle$ Anna Kharchenko, PhD, Associate Professor, Department of Transport Construction and Property Management, National Transport University, Kyiv, Ukraine, e-mail: anna-x3@ukr.net, ORCID: https:// orcid.org/0000-0001-8166-6389

$\triangle$ Corresponding author 